\title{
Study the Profile of the Turmeric Growers in Hingoli District, India
}

\author{
S. S. Shende ${ }^{1}$, R. D. Ahire ${ }^{1}$ and R. B. Kalamkar ${ }^{2 *}$ \\ ${ }^{1}$ Department of Extension Education, College of Agriculture, Vasantrao Naik Marathwada \\ Krishi Vidyapeeth, Parbhani, India \\ ${ }^{2}$ Department of Extension Education, College of Agriculture, Baramati (MS), India \\ *Corresponding author
}

\section{A B S T R A C T}

\section{Keyw ords \\ Turmeric, Curcuma longa, Grower}

\section{Article Info}

Accepted:

17 October 2020

Available Online:

10 November 2020
The present study was conducted with specific objective to study the Entrepreneurial Eehaviour of Turmeric Growers in Hingoli District the study was conducted in Hingoli District of Maharashtra. The study was purposively conducted in Vasmat and Aundha tahsils of Hingoli district as a major area under turmeric cultivation. Keeping in view the objectives of the study, an interview schedule was designed. This includes relevant questions for seeking information in respect of independent and dependent variables. The data were collected through face to face contact method by contacting the selected farmers. The majority 61.34 per cent of respondents were from middle age group, followed by old age group 25.33 per cent and young age group 13.33 per cent respectively, the majority 38.00 per cent of respondents were educated up to High school, where as one third 24.67 per cent up to College level. About 16.67 per cent respondents educated up to Middle school and very few 11.33 per cent was found in primary whereas 06.00 per cent and 03.33 per cent of the respondents are illiterate and can read and write respectively, the majority, more than half of the turmeric grower 69.33 per cent had medium family size whereas, 22.00 per cent of turmeric grower belonged to small family size, Thus, 08.67 per cent of turmeric growers belonged to big family size the majority 71.33 per cent of the turmeric growers had medium experience in turmeric production for a period ranging between 8 to 17 years, followed by 18.00 per cent of respondents had low experience the majority that 77.33 per cent of the respondents had well or tube well their source of irrigation, canal 20.00 per cent and remaining 02.67 per cent of the respondents had river as their source of irrigation. Thus, the study concluded that maximum number of the respondents had well or tube well as their source of irrigation. Maximum percentage of the turmeric growers were found in semi-medium and medium land holding category. The reason for possession of higher per cent of semi medium land holding could be due to fragmentation of land because of separation of families. majority 76.00 per cent had annual income of Rs. 99176 to Rs. 380824, followed by 15.33 per cent of the respondent had annual income of below Rs. 99175 and only 08.67 per cent had annual income of Rs.380822 and above more than two third 64.00 per cent of respondents uses medium sources of information followed by, low 20.00 per cent and high category of sources of information 16.00 per cent respectively. more than two third 64.00 per cent of respondents uses medium sources of information followed by, low 20.00 per cent and high category of sources of information 16.00 per cent respectively the majority 77.33 per cent of the turmeric growers had high social participation, while, 12.67 per cent of turmeric growers were having medium level of social participation. Only, 10.00 per cent of them had low social participation .majority 69.33 per cent of the respondents had medium risk bring ability. Whereas, 20.00per cent had low and10.67 per cent of respondents had high level of risk bearing ability the majority indicated that, more than half of respondent 70.00 per cent had medium level of market orientation, whereas 16.67 per cent of respondent had low market orientation and 13.33 per cent of respondent found high market orientation. 


\section{Introduction}

Turmeric (Curcuma longa L), the ancient and sacred spice of India known as „Indian saffron $^{\text {ee }}$ is an important commercial spice crop grown in India. The word "turmeric" is derived from the Latin word "terra merita" which means "meritorious earth" referring to the colour of ground turmeric.

Turmeric is popular in different names in different local languages in India. "Haldi", a word derived from Sanskrit word "Haridra", is commonly used in North India for turmeric. In South India, it is known in the name of "Manjal", a word obtained from ancient Tamil literature.

Turmeric (Curcuma longa L.) is a wellknown medicinal plant of family Zingiberaceae. It is used in diversified forms as a condiment, flavouring and coloring agent and as a principal ingredient in Indian kitchen as a curry powder. It has anti cancer and anti viral activities and hence finds use in the drug industry and cosmetic industry. 'Kum-kum', popular with every house wife, is also a byproduct of turmeric. It finds a place in offerings on religious and ceremonial occasions.. India is the largest producer of turmeric in the whole world.

The use of turmeric in India was dated 4000 years back as evident from Vedic culture. It might have reached to China in 700AD, then to East Africa by $800 \mathrm{AD}$ and later to West Africa.

In Maharashtra the turmeric is mainly grown in districts Sangli, SataraKolhapur, Hingoli, Parbhani and Nanded. Among spices, turmeric is ranked second in export earning in India. Turmeric from India is mostly exported as fresh and dried whole root (rhizome), in powdered form, and processed form, such as oil and oleoresin, mainly to UK, USA, Japan, the Netherland, Iran, UAE, Bangladesh, France and South Africa. India has monopoly in turmeric trade at world level

\section{Materials and Methods}

\section{Research design}

The Ex-post-facto design was used for the present research study. Kerlinger (1976) stated that ex-post-facto research design is worthy to apply when the independent variables have already acted upon.

Sampling procedure: It includes the following aspects

\section{Selections of Tahasil}

The study was purposively conducted in Vasmat and Aundha tahsils of Hingoli district as a major area under turmeric cultivation.

\section{Selection of villages}

List of turmeric growing villages was prepared in consultation with Taluka agriculture officer of Vasmat and Aundha tahasil. From the list ten villages having maximum area under turmeric crop were selected.

\section{Selection of respondents}

Respondents who have cultivated turmeric on more than 0.20 ha. Area were selected the list of respondents was obtained from talathi and from each village 15 respondents was drawn by nth method of random sampling. Thus, final sample was comprised of 150 respondents.

\section{Designing of interview schedule}

Keeping in view the objectives of the study, an interview schedule was designed. This 
includes relevant questions for seeking information in respect of independent and dependent variables.

The questions asked were in local language (i.e. Marathi). The schedule was pretested from respondents who are not included in study the schedule included both open and close ended questions.

\section{Pre-testing of Schedule}

The pre-testing of schedule is necessary on the part of researchers, in order to know the mistakes, ambiguities and shortfalls. Pretesting is also essential for clarity, readability, and validity. Before finalizing the interview schedule it was pre- tested outside the sample area for reliability and validity of the questions by interviewing fifteen respondents.

\section{Method of data collection}

The data were collected through face to face contact method by contacting the selected farmers. The

\section{Processing of data}

The information collected from the turmeric growers with the help of the personal interview schedule was processed by making primary and secondary tables.

The data of qualitative nature were converted into quantitative form and computation of score was done for each of the independent and dependent variables.

The information collected was transferred from the interview schedule to primary tables and to secondary tables. farmers were contacted at their home or farm as per their convenience.

\section{Results and Discussion}

\section{Socio-economic characteristics of the turmeric growers}

Age

Age was considered as a factor, since it reveals the ability of an individual to take positive decisions for achieving his needs and it influences the turmeric growers to choose and to adopt a particular technology. The results related to the age distribution of turmeric growers are presented in the table 1.

The above Table 1 concluded that the majority 61.34 per cent of respondents were from middle age group, followed by old age group 25.33 per cent and young age group 13.33 per cent respectively.

The middle age farmers comparatively have free hands in financial affairs and they can take decisions independently to implement their ideas. Farmers of middle age are of enthusiastic, having moderate experience in turmeric and have more efficiency than older once.

This similar finding was also reported by Kanwat (2011), Kaushalkumar (2012), Thakare (2013), Ahire and Kapse (2015) and Kamble

\section{Education}

The above Table 2 concluded that the majority 38.00 per cent of respondents were educated up to High school, where as one third 24.67 per cent up to College level. About 16.67 per cent respondents educated up to Middle school and very few 11.33 per cent was found in primary whereas 06.00 per cent and 03.33 per cent of the respondents are illiterate and can read and write respectively. 
As the respondents are staying in and around the city place which might be realized them the importance of formal education and motivated to pursue higher education it can be the probable reason for majority of farmers to be educated up to High school level.

This was due to as education of respondent increases then there is increase in the knowledge of respondents so it helps in carrying out better entrepreneurial activity.

This observation is similar with findings of Kumar (2011), Kaushalkumar (2012), Shinde (2014), Kamble (2015), Ahire and Kapse (2015)

The above Table 2 concluded that the majority 61.34 per cent of respondents were from middle age group, followed by old age group 25.33 per cent and young age group 13.33 per cent respectively.
The middle age farmers comparatively have free hands in financial affairs and they can take decisions independently to implement their ideas. Farmers of middle age are of enthusiastic, having moderate experience in turmeric and have more efficiency than older once.

\section{Family size}

The above Table 3 concluded that the majority, more than half of the turmeric grower 69.33 per cent had medium family size whereas, 22.00 per cent of turmeric grower belonged to small family size. Thus, 08.67 per cent of turmeric growers belonged to big family size.

Similar result found by Ekhande (2016), Chauhan et al., (2004), Nagesha (2005) and Pandeti (2005)

Table.1 Distribution of the respondents according to their age

\begin{tabular}{|c|c|c|c|}
\hline Sr. No. & Age & \multicolumn{2}{c|}{ Respondents $(\mathbf{n = 1 5 0})$} \\
\hline & & Number & Percentage \\
\hline 1 & Young (Up to 27 yrs.) & 20 & 13.33 \\
\hline 2 & Middle (28 yrs. to 53 yrs.) & 92 & 61.34 \\
\hline 3. & Old (54 yrs. and above) & 38 & 25.33 \\
\hline & Total & $\mathbf{1 5 0}$ & $\mathbf{1 0 0 . 0 0}$ \\
\hline
\end{tabular}

Table.2 Distribution of the respondents according to their education

\begin{tabular}{|c|l|c|c|}
\hline \multirow{2}{*}{$\begin{array}{c}\text { Level of education } \\
\text { Sr. No. }\end{array}$} & \multicolumn{2}{|c|}{$\begin{array}{c}\text { Respondents }(\mathbf{n = 1 5 0}) \\
\text { Pumber }\end{array}$} \\
\hline 1. & Illiterate & 9 & 06.00 \\
\hline 2. & Can read and write & 5 & 03.33 \\
\hline 3. & Primary school $\left(1^{\text {st }}\right.$ to $\left.4^{\text {th }}\right)$ & 17 & 11.33 \\
\hline 4. & Secondary education $\left(5^{\text {th }}\right.$ to $\left.10^{\text {th }}\right)$ & 25 & 16.67 \\
\hline 5. & High school $\left(11^{\text {th }}\right.$ to $\left.12^{\text {th }}\right)$ & 57 & 38.00 \\
\hline 6. & College level/ graduate/diploma & 37 & 24.67 \\
\hline & Total & $\mathbf{1 5 0}$ & $\mathbf{1 0 0 . 0 0}$ \\
\hline
\end{tabular}


Table.3 Distribution of turmeric growers according to their size of family

\begin{tabular}{|c|c|c|c|}
\hline Sr. No. & Category & Frequency & Percentage \\
\hline 1 & Small ( up to 4$)$ & 33 & 22.00 \\
\hline 2 & Medium ( 5 to 10$)$ & 104 & 69.33 \\
\hline 3 & Big (11 and above) & 13 & 08.67 \\
\hline & Total & $\mathbf{1 5 0}$ & $\mathbf{1 0 0 . 0 0}$ \\
\hline
\end{tabular}

Table.4 Distribution of the respondents according to their experience

\begin{tabular}{|c|l|c|c|}
\hline Sr. No. & Experience & \multicolumn{2}{|c|}{ Respondents (n=150) } \\
\hline & & Number & Percentage \\
\hline 1 & Low (upto 7 years) & 27 & 18.00 \\
\hline 2 & medium (8 to 17 years) & 107 & 71.33 \\
\hline 3 & High (18 years \& above) & 16 & 10.67 \\
\hline & T & $\mathbf{1 5 0}$ & $\mathbf{1 0 0 . 0 0}$ \\
\hline
\end{tabular}

Table.5 Distribution of the respondents according to their source of irrigation

\begin{tabular}{|c|l|c|c|}
\hline \multirow{2}{*}{ Sr. No. } & Source of irrigation & \multicolumn{2}{|c|}{ Respondents $(\mathbf{n}=\mathbf{1 5 0})$} \\
\hline & & Number & Per cent \\
\hline 1. & River & 4 & 02.67 \\
\hline 2. & Well / Tube well & 116 & 77.33 \\
\hline 3. & Canal & 30 & 20.00 \\
\hline Total & & $\mathbf{1 5 0}$ & $\mathbf{1 0 0 . 0 0}$ \\
\hline
\end{tabular}

Table.6 Distribution of the respondents according their size of land holding

\begin{tabular}{|c|l|c|c|}
\hline Sr. No. & \multicolumn{1}{|c|}{ Land holding } & \multicolumn{2}{c|}{ Respondents $(\mathbf{n = 1 5 0})$} \\
\hline & & Number & Percentage \\
\hline 1. & Marginal (Up to 1.00 ha.) & 29 & 19.34 \\
\hline 2. & Small (1.01 ha.to 2.00 ha.) & 49 & 32.67 \\
\hline 3. & Semi-medium (2.01 ha.to 4.00 ha.) & 53 & 35.33 \\
\hline 4. & Medium (4.01 ha. to 10.00 ha.) & 11 & 07.33 \\
\hline 5. & Big (10.10 ha.\& above) & 8 & 05.33 \\
\hline & Total l & $\mathbf{1 5 0}$ & $\mathbf{1 0 0 . 0 0}$ \\
\hline
\end{tabular}

Table.7 Distribution of the respondents according to their annual income

\begin{tabular}{|c|c|c|c|}
\hline Sr. No. & Annual income & \multicolumn{2}{|c|}{ Respondents $(\mathbf{n = 1 5 0})$} \\
\hline & & Number & Percentage \\
\hline 1. & Low (Up to 99176) & 23 & 15.33 \\
\hline 2. & Medium (99177 to 380823) & 114 & 76.00 \\
\hline 3. & High (380824\& Above) & 13 & 8.67 \\
\hline & Total & $\mathbf{1 5 0}$ & $\mathbf{1 0 0 . 0 0}$ \\
\hline
\end{tabular}


Table.8 Distribution of the respondents according to their use of source of information

\begin{tabular}{|c|c|c|c|}
\hline Sr. No. & \multicolumn{2}{|c|}{ Sources of information } & \multicolumn{2}{|c|}{ Respondents $(\mathbf{n = 1 5 0})$} \\
\hline 1. & Low ( up to 4) & Number & Percentage \\
\hline 2. & Medium ( 5 to 17) & 30 & 20.00 \\
\hline 3. & High ( 18 and above ) & 96 & 64.00 \\
\hline & Total & 24 & 16.00 \\
\hline
\end{tabular}

Table.9 Distribution of turmeric growers according to their social participation

\begin{tabular}{|c|l|c|c|}
\hline Sr. No. & Category & Frequency & Percentage \\
\hline 1. & Low ( up to 7$)$ & 19 & 12.0000067 \\
\hline 2. & Medium $(8$ to 11$)$ & 116 & 77.33 \\
\hline 3. & High $(12$ and above $)$ & 15 & 10.00 \\
\hline & Total & $\mathbf{1 5 0}$ & $\mathbf{1 0 0 . 0 0}$ \\
\hline
\end{tabular}

Table.10 Distribution of the respondents according to their risk orientation

\begin{tabular}{|c|c|c|c|}
\hline Sr. No. & Risk orientation & \multicolumn{2}{|c|}{ Respondents $(\mathbf{n = 1 5 0})$} \\
\hline & & Number & Percentage \\
\hline 1. & Low ( up to 12) & 30 & 20.00 \\
\hline 2. & Medium (13 to 25) & 104 & 69.33 \\
\hline 3. & High (26 and above) & 16 & 10.67 \\
\hline & Total l & $\mathbf{1 5 0}$ & $\mathbf{1 0 0 . 0 0}$ \\
\hline
\end{tabular}

Table.11 Distribution of the respondents according to their Market orientations

\begin{tabular}{|c|l|c|c|}
\hline Sr. No. & Market orientation & \multicolumn{2}{|c|}{ Respondents $(\mathbf{n = 1 5 0})$} \\
\hline & & Number & Percentage \\
\hline 1. & Low( up to 17) & 25 & 16.67 \\
\hline 2. & Medium(18 to 26) & 105 & 70.00 \\
\hline 3. & High( 27 and above $)$ & 20 & 13.33 \\
\hline & T & $\mathbf{1 5 0}$ & $\mathbf{1 0 0 . 0 0}$ \\
\hline
\end{tabular}

These results are in similar with Pisure (2012), Chikane (2018)

\section{Experience in turmeric production}

Experience is the important factor, which influence the decision making ability, management ability and help the turmeric producer in taking calculated risk. Apart from this it also influence the social and economic status of the turmeric growers. The information pertaining to the experience of the respondents were collected, tabulated and analyzed. The results are presented in the table

The above Table 4 concluded that the majority 71.33 per cent of the turmeric growers had medium experience in turmeric 
production for a period ranging between 8 to 17years, followed by 18.00 per cent of respondents had low experience in the turmeric production for a period ranges up to 7 years. The 10.67 per cent of the respondents had high experience in the turmeric production for a period ranging between 18and above years.

The probable reason for most of the turmeric growers had medium experience and most of them are middle age group. The experience helps turmeric growers improve their decision making ability, management orientation and risk taking ability. Apart from that it helps them to improve their socio-economic status. This was due to as farming experience of respondents had more then there is similarly increase in entrepreneurial attributes of respondents. This observation is similar with findings of Sonwane et al., (2009), Kumar (2011), Kaushalkumar (2012), and Lad (2014), Ekhande (2016)

\section{Source of irrigation}

The sources of irrigation are quite useful to increase the productivity hence, it is included in the study and result has been presented in Table 5

The above Table 5 concluded that the majority that 77.33 per cent of the respondents had well or tube well their source of irrigation, canal 20.00 per cent and remaining 02.67 per cent of the respondents had river as their source of irrigation. Thus, the study concluded that maximum number of the respondents had well or tube well as their source of irrigation.

\section{Land holding}

It is concluded that maximum percentage of the turmeric growers were found in semimedium and medium land holding category.
The reason for possession of higher per cent of semi medium land holding could be due to fragmentation of land because of separation of family (Table 6).

\section{Annual income}

The above Table 7 concluded that majority 76.00 per cent had annual income of Rs. 99176 to Rs. 380824 , followed by 15.33 per cent of the respondent had annual income of below Rs. 99175 and only 08.67 per cent had annual income of Rs.380822 and above.

\section{Sources of information}

Sources of information help to seek knowledge and guidance about many aspects of turmeric growers. The information sources not only provide information but also provide some guidance along with information. Apart from this it also plays vital role in acquiring latest improved turmeric technology, motivated turmeric growers for its adoption and that helpful for adopting new technology. The result obtained has been presented in table 8 . The Table 8 indicated that more than two third 64.00 per cent of respondents uses medium sources of information followed by, low 20.00 per cent and high category of sources of information 16.00 per cent respectively.

Most of the respondents preferred individual contact methods i.e. discussion with friends, colleagues and get information from successful turmeric growers. Apart from this they used group contact methods like demonstrations and organization of turmeric grower's etc. for getting information related to turmeric enterprise.

\section{Social participation}

The above Table 9 concluded that the majority 77.33 per cent of the turmeric 
growers had high social participation, while, 12.67 per cent of turmeric growers were having medium level of social participation. Only, 10.00 per cent of them had low social participation.

\section{Risk orientation}

The below Table 10 concluded that the majority 69.33 per cent of the respondents had medium risk bring ability. Whereas, 20.00 per cent had low and 10.67 per cent of respondents had high level of risk bearing ability.

\section{Market orientation}

The Table 11 concluded that the majority indicated that, more than half of respondent 70.00 per cent had medium level of market orientation, whereas 16.67 per cent of respondent had low market orientation and 13.33 per cent of respondent found high market orientation. The reason behind such findings may be the turmeric grower were having medium farming experience and having education level up to higher secondary school. Also this might be due to moderate social participation and medium sources of information.

In conclusion the entrepreneurs were in medium age group are prominent in turmeric production Not only all the turmeric growers are literate but considerable numbers of them are highly educated. A large number of the turmeric growers have do this business since many years. Majority of them need to be encouraged to develop risk orientation amongst them. That 96.66 per cent of the respondents had expressed unavailability of nutrient at proper time. Whereas 94.66 per cent of the respondents expressed High cost of labour. Lack of guidance for control pest and disease problems were faced by the 90.66 per cent of the respondents. Lack of market knowledge, Use of pressure cooker for processing is costly and exploitation by middleman are the major problems of the turmeric growers respectively. Unavailability of nutrient at proper time the major problem for Most of the turmeric growers.

\section{References}

Kanwat,M. and Mishra,B.P., Suresh Kumar, P. and Bhagwati R. (2011). Knowledge level and socio-economic profile of the Khasi Mandarin (Citrus reticulata) growers in Arunachal Pradesh. Asian J. Ext. Edu. 29: 40-44.

Kaushalkumar (2012). Entrepreneurial behaviour of pineapple growers. Indian Research journal of extension education special issue (Volume I), 142-145.

Thakare, A.K. (2013). Entrepreneurial attributes of floriculturists M.Sc. (Agri.) (Unpublished) Thesis, submitted to Dr. PDKV, Akola (M.S.).

Ahire, R.D. and Kapse, P.S (2015) Socioeconomic Impact of Commodity Interest Group among Pomegranate Growers. Agrosco Report 2014-2015 VNMKV, Parbhani.

Chikane S.R. (2018) Entrepreneurial behaviour of self help group members M.Sc. (Agri.) Thesis (Unpub) VNMKV , Parbhani (MS)

Kaushalkumar (2012). Entrepreneurial behaviour of pineapple growers. Indian Research journal of extension education special issue (Volume I), $142-145$.

Kumar, A.B. (2011). Conducted a study on entrepreneurial qualities and adoption behavior of banana growers in Gulbarga district of Karnataka. M.Sc. thesis (Unpublished) UAS, Dharwad.

Kamble, V.B., Suradkar, D.D. and Deshmukh, J.M (2015) Impact evaluation of Front line Demonstration 
on Safflower Growers in Latur District. Agrosco Report 2014-2015 VNMKV, Parbhani.

Lad, A.S. (2014). Utility perception of mass media by the farm women. Ph.D (Agri.) Thesis, VNMKV, Parbhani

Nagesha. (2005). Study on entrepreneurial behaviour of vegetable seed Producing farmers in Haveri district of Karnataka. M.Sc (Agri) Thesis (Unpub.) UAS, Dharwad.

Ekhande Y.S. (2016) Entrepreneurial behavior of sweet orange growers in Marathwada region M.sc (Agri) Thesis (Unpub) VNMKV, Parbhani (MS)

Pisure, B.L., Thombre, B.M. and V.N. Sidam,
(2014). Relationship between personal, socio-economical and psychological characteristics of dairy farmers and their entrepreneurial behaviour. International Journal of Farm Sciences 4(4): 264-271.

Shinde, P.B (2014) Knowledge and adoption of recommended seed production technology of soybean by the growers. M.Sc. (Agri.) Thesis, VNMKV, Parbhani.

Sonawane, H. P., Shirke, V.S. and Ahire, M. C. (2009). Study of strawberry growers from Mahabaleshwar tahsil of Satara district (Maharashtra). Asian J. Extn. Edu. 27: 91 - 95 .

\section{How to cite this article:}

Shende, S. S., R. D. Ahire and Kalamkar, R. B. 2020. Study the Profile of the Turmeric Growers in Hingoli District, India. Int.J.Curr.Microbiol.App.Sci. 9(11): 2397-2405.

doi: https://doi.org/10.20546/ijcmas.2020.911.288 